\title{
EFFECT OF SHEAR WALL CONFIGURATION ON SIESMIC BEHAVIOR OF A TYPICAL RC TALL BUILDING
}

\author{
Abhishek K K ${ }^{1}$, Rajeeva S V ${ }^{2}$ \\ ${ }^{I}$ M.Tech.(Structural Engineering), Department of Civil Engineering, SJBIT, Karnataka, India \\ ${ }^{2}$ Professor, Department of Civil Engineering, SJBIT, Karnataka, India
}

\begin{abstract}
Application of shear wall are most appropriate structural form that is designed to resist shear i.e, the lateral force causes the severe damage on the structural elements during earthquakes. The aim of this work is to study the structural behavior of an RC Building with $G+19$ stories are to be considered for lateral forces using different shear wall configuration. Non-linear analysis was done in the CYPE-CAD to check the lateral force resistant behavior of structural system. This analytical investigation on RC shear wall systems for lateral load resisting is compared with ordinary $R C$ structures. By providing shear wall the lateral forces are resisted by the structural system which have increased stiffness, deformability and decreases drift. The analytical investigation of the ordinary RC structures and shear wall systems has been done using the parameters - storey displacement, storey drift, and base shear. Also, the forces on the columns has been studied.
\end{abstract}

Keywords: Shear wall configuration, displacement, drifts, shear force, Bending moments, etc. $* * *$

\section{INTRODUCTION}

Earthquakes are natural hazards under which disasters are mainly caused by damage to or collapse of buildings and other man-made structures. So,it is very necessary to keep in mind the hazards due to seismic effects and should adopt the necessary assumption before design. Because the structures are vulnerable to severe damages due to earthquake.

A Tall building are the demand of present situation. As the height of structureincreases, lateral forces due to seismic becomes predominant. The major portion of these shall be resisted by the structural elements. Shear wall system are one of the most commonly used lateral load resisting in high rise building.

Most of the previous investigators have analysed frame-wall system by adopting 2D model for analysis. As the structure chosen was symmetrical and often not very tall, however, 2D analysis cannot adequately take into account the torsional affects and asymmetric effect induced due lateral force.

\section{LITERATURE REVIEW}

Shahzad Jamil Sardar (2013) [1]: Explains that shear wall is a structural element used to resist horizontal forces parallel to the plane of the wall. Shear wall has highly in plane stiffness and strength which can be used to simultaneously resist large horizontal loads and support gravity loads. Shear Walls are specially designed structural walls include in the buildings to resist horizontal forces that are induces in the plane of the wall due to wind, earthquake and other forces.
Karthick S (2016) [2]: Explains the analysis of RC building for seismic analysis using different type of structural systems. Shear walls and bracing systems are the most appropriate structural forms in the recent decades. A shear wall is a wall that is designed to resist shear i.e. the lateral force that causes bulk damage to the structures during earthquakes. Bracing is also a highly efficient and economical method of resisting horizontal forces in a frame structures.

Shivanand C. Ghule et al (2015) [3]: Explains the Failure of reinforced concrete structures during the past earthquakes has taught us the importance of evaluation of the seismic capacity of the existing buildings. Presence of irregularities is considered as a major deficiency in the seismic behaviour of structures. Introduction of bracings and stiff shear walls are the popular methods of strengthening the buildings against their poor seismic performance.

Raghavendra et al (2016) [5]: The this study author made an attempt to understand the effect of earthquake on building frames resting on sloping ground with shear walls and bracings under severe zone. The computation models of ordinary moment resisting frame was developed in SAP2000 as 3D space frame to carry the seismic analysis as per IS 1893 Part (I) -2002. This study may help to understand the effect of buildings on sloping ground under seismic forces to suggest the efficient lateral force resisting configuration based on parametric study.

\section{OBJECTIVES}

(i) To investigate the behaviour of RC Tall Building with different structural configuration in Zone-V.

(ii) To studythe parameters such as displacement, drift, base shear of structural configuration with bare frame. 
(iii) To study the column forces of the structural configurations.

(iv) Ranking of configuration investigated.

\section{MODELLING}

The analysis of all the structural configurations and bare frame for the (G+19 storeys) have been analysed for lateral loads. CYPE-CAD has been used for the modelling and to carry out the analysis. The analysis results are obtained for seismic zone $\mathrm{V}$.

\subsection{Model Data}

Table 4.1: Details of building model

\begin{tabular}{|l|l|}
\hline Building Description & Details \\
\hline Plan dimension & $42 \mathrm{mx} 20 \mathrm{~m}$ \\
\hline Story height & $3 \mathrm{~m}$ \\
\hline Size of beams & $250 \times 600 \mathrm{~mm}$ \\
\hline Size of corner columns & $600 \times 600 \mathrm{~mm}$ \\
\hline Size of column & $350 \times 1200 \mathrm{~mm}$ \\
\hline Thickness of slab & $150 \mathrm{~mm}$ \\
\hline Thickness of shear wall & $200 \mathrm{~mm}$ \\
\hline Density of reinforced concrete & $25 \mathrm{kN} / \mathrm{m}^{3}$ \\
\hline Density of brick & $20 \mathrm{kN} / \mathrm{m}^{3}$ \\
\hline Dead load & $1.5 \mathrm{kN} / \mathrm{m}^{2}$ \\
\hline Live load & $4 \mathrm{kN} / \mathrm{m}^{2}$ \\
\hline Seismic zone factor & $\mathrm{V}$ \\
\hline Importance factor (I) & 1 \\
\hline Response reduction factor (R) & 5 \\
\hline Type of soil & $\mathrm{Type}-2$ \\
\hline $\begin{array}{l}\text { Grade of Concrete for slabs and } \\
\text { beams }\end{array}$ & $\mathrm{M} 25$ \\
\hline $\begin{array}{l}\text { Grade of Concrete for columns } \\
\text { and shear wall }\end{array}$ & $\mathrm{M} 40$ \\
\hline Grade of Steel & 415 \\
\hline
\end{tabular}

\subsection{Structural Configurations of the Tall Building}

1. Bare Frame

2. Internal shear wall (ISW)

3. External shear wall (ESW)

4. Lift core wall (LCW)

5. Parallel shear wall (PSW)

6. Centre shear wall (CSW)

7. Corner side shear wall (2CSW)

8. Combination of centre and corner shear wall (CSW \& ESW)

\subsection{Typical Plan}

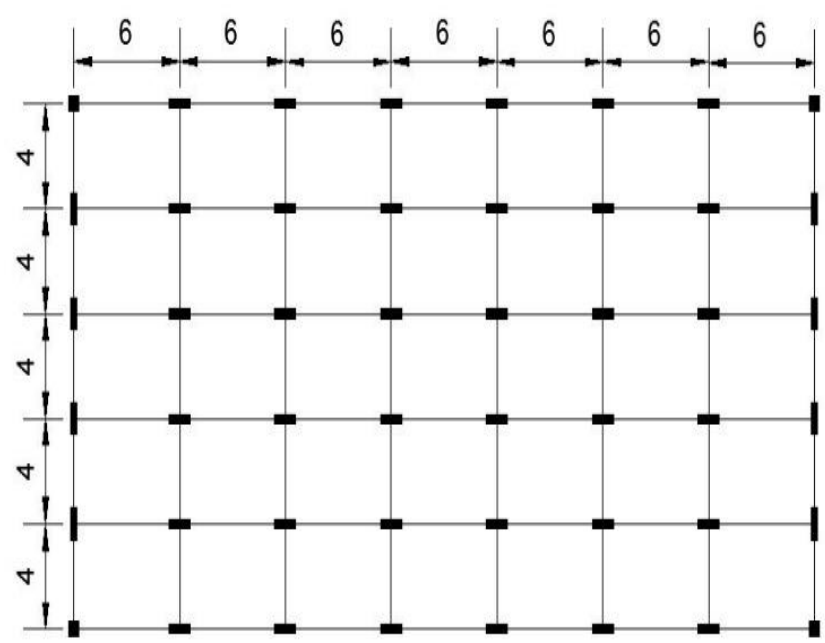

Fig 4.1: Typical layout plan of building

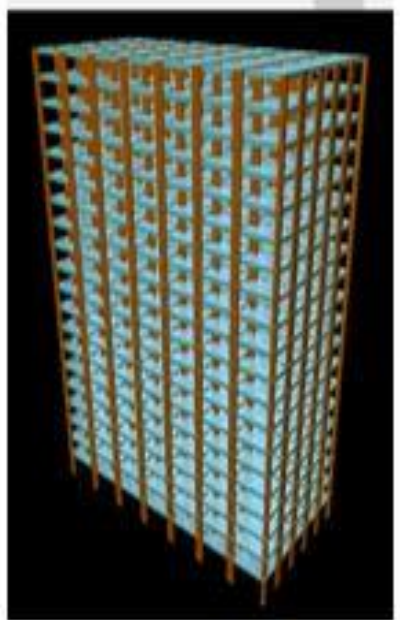

Fig.4.2 Bare frame

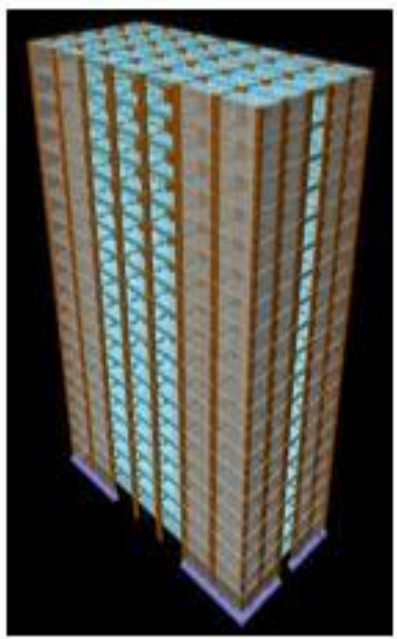

Fig. 4.4 ESW

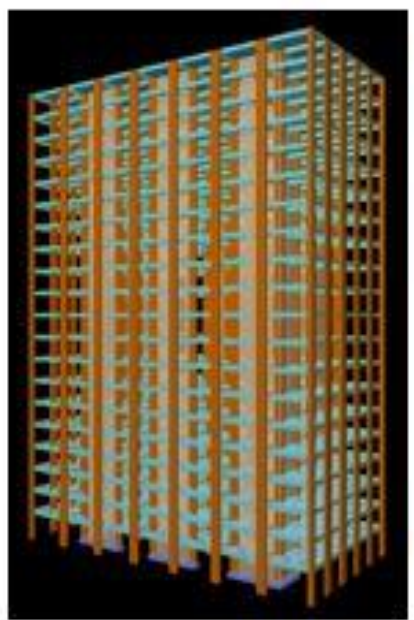

Fig. 4.3 ISW

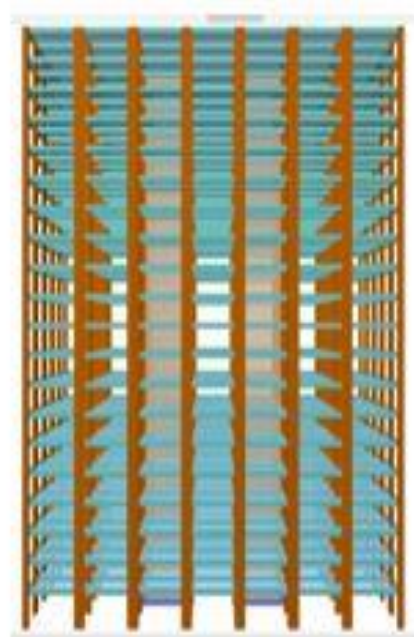

Fig. 4.5 LCW 


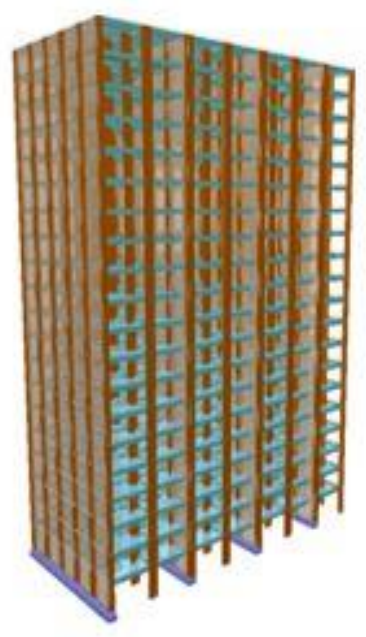

Fig. 4.6 PSW
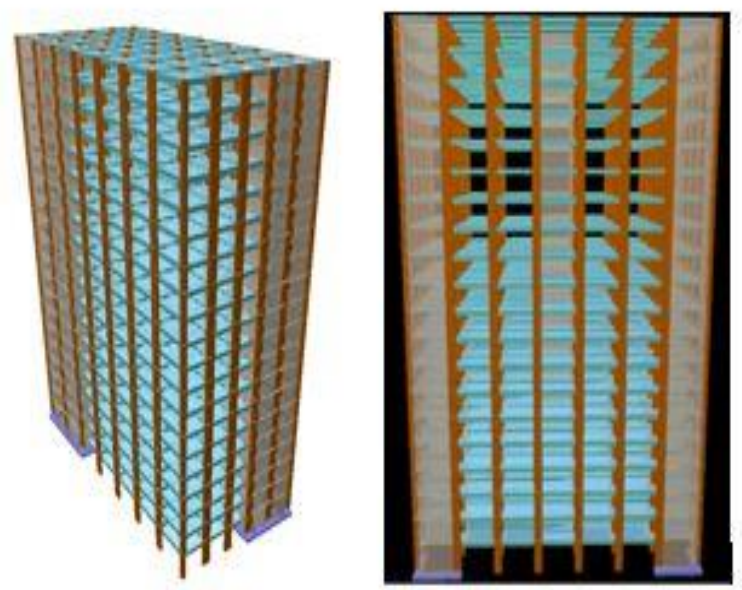

Fig. 4.8 2CSW

Fig. 4.9 Comb. CSW\&ESW

\section{RESULTS AND DISCUSSIONS}

Storey displacement, storey drifts, base shear, Shear force and Bending moments are taken from the software. The comparison between Bare frame and other shear wall structural configurations for the parameters mentioned above presented in tables and figures below.

\subsection{Maximum Storey Displacements}

The table and Fig below shows the maximum displacement values for the different Structural Configuration.

Table 5.1 Maximum displacement in $\mathrm{X}$ and $\mathrm{Y}$ direction

\begin{tabular}{|l|l|l|}
\hline \multicolumn{2}{|l|}{ Shear wall System } \\
\hline \multirow{2}{*}{$\begin{array}{l}\text { CONFIGURATION } \\
\text { SYSTEM }\end{array}$} & \multicolumn{2}{|l|}{ LATERAL } \\
& DISPLACEMENT (mm) \\
\cline { 2 - 3 } & UX & UY \\
\hline Bare Frame & 98.47 & 126.54 \\
\hline ISW & 37.68 & 66.88 \\
\hline ESW & 19.18 & 29.13 \\
\hline
\end{tabular}

\begin{tabular}{|l|l|l|}
\hline LCW & 49.31 & 77.29 \\
\hline PSW & 65.08 & 101.04 \\
\hline CSW & 19.93 & 41.15 \\
\hline 2CSW & 16.88 & 29.65 \\
\hline COMB CSW \& ESW & 38.84 & 56.32 \\
\hline
\end{tabular}

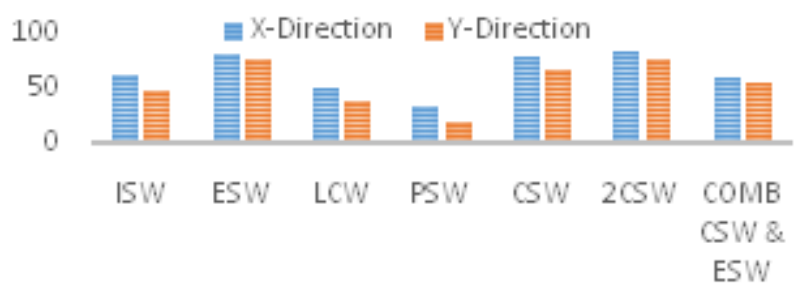

Fig. 5.1 Percentage reduction of lateral displacement

From table 5.1 and Fig.5.1 it can be observed that the lateral displacements along $\mathrm{X}$ and $\mathrm{Y}$ directions are reduced effectively in all the shear wall configurations. For ESW, CSW and 2CSW lateral displacement has been reduced by around $81 \%, 80 \%$ and $82 \%$ respectively in comparison with Bare frame.

\subsection{Maximum Storey Drifts}

The table and Fig below shows the maximum drift ratios for the different models.

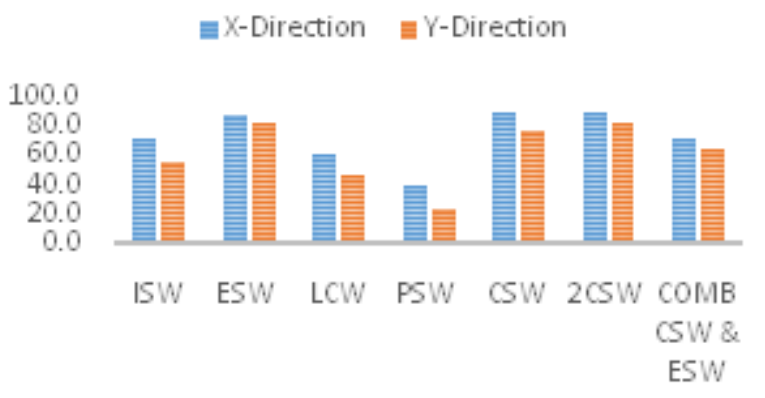

Fig. 5.2 Percentage reduction of Storey drift

From Fig.5.2 it can be observed that the driftsare reduced in all the configurations in the range $50 \%$ to $89 \%$ along $X$ and Y directions except PSW which reduced by around $38 \%$.

\subsection{Base Shear}

The table and Fig below shows the base shear values for the different models.

Table 5.3 Base shear

\begin{tabular}{|l|l|}
\hline Confg. System & Base shear(KN) \\
\hline Bare Frame & 12329 \\
\hline ISW & 12776 \\
\hline ESW & 12968 \\
\hline LCW & 12296 \\
\hline PSW & 12498 \\
\hline
\end{tabular}




\begin{tabular}{|ll|l|}
\hline CSW & 12217 \\
\hline 2CSW & & 12240 \\
\hline $\begin{array}{l}\text { COMB CSW \& } \\
\text { ESW }\end{array}$ & 12261 \\
\hline
\end{tabular}

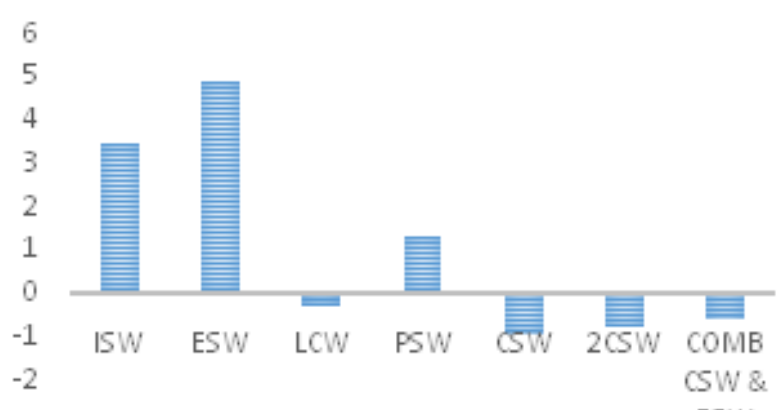

From table 5.3 and Fig.5.3 it can be observed that ISW, ESW and PSW increased its base shear by $3.5 \%, 5 \%$ and $1.2 \%$ respectively. While other configurations are reduced in the range $0.5 \%$ to $1 \%$ when compared to bare frame.

\subsection{Column Forces}

The table and Fig below shows the column forces of interior and the column near the re-entrant corner for the irregular models.

Fig. 5.3 Percentage increase in Base shear

Table 5.5: Shear Forces in Selected columns

\begin{tabular}{|l|l|l|l|l|l|l|l|l|}
\hline \multicolumn{1}{|l|}{ Shear Force in kN } & BARE & ISW & ESW & LCW & PSW & CSW & 2CSW & $\begin{array}{l}\text { COMB CSW } \\
\text { \& ESW }\end{array}$ \\
\hline COLUMN & 103 & 71 & 217 & 135 & 191 & 121 & 305 & 334 \\
\hline C1 & 509 & 176 & 498 & 205 & 457 & 222 & 461 & 609 \\
\hline C2 & 517 & 181 & 228 & 219 & 464 & 595 & 200 & 177 \\
\hline C4 & 497 & 131 & 98 & 698 & 485 & 100 & 288 & 338 \\
\hline C31 & 498 & 117 & 104 & $\mathbf{8 8 9}$ & 484 & 96 & 207 & 422 \\
\hline C38 &
\end{tabular}

Table 5.6: Bending Moment in selected columns

\begin{tabular}{|l|l|l|l|l|l|l|l|l|}
\hline \multicolumn{1}{|l|}{ Shear Force in kN(For Bracing System) } \\
\hline COLUMN & BARE & DBS & XBS & EBS & IVBS & KBS & VBS & $\begin{array}{l}\text { COMB } \\
\text { DBS \&XBS }\end{array}$ \\
\hline C1 & $\mathbf{1 0 3}$ & $\mathbf{9 1}$ & $\mathbf{8 2}$ & $\mathbf{7 2}$ & $\mathbf{9 2}$ & $\mathbf{9 1}$ & $\mathbf{9 3}$ & $\mathbf{8 7}$ \\
\hline C2 & $\mathbf{5 0 9}$ & $\mathbf{5 1 7}$ & $\mathbf{5 2 8}$ & $\mathbf{5 2 7}$ & $\mathbf{5 1 8}$ & $\mathbf{2 1 4}$ & $\mathbf{5 2 2}$ & $\mathbf{5 2 8}$ \\
\hline C4 & $\mathbf{5 1 7}$ & $\mathbf{5 3 2}$ & $\mathbf{5 4 1}$ & $\mathbf{5 3 1}$ & $\mathbf{5 3 3}$ & $\mathbf{5 3 4}$ & $\mathbf{3 1 9}$ & $\mathbf{5 3 5}$ \\
\hline C31 & 497 & $\mathbf{5 0 4}$ & $\mathbf{5 1 0}$ & $\mathbf{5 0 3}$ & $\mathbf{5 0 4}$ & $\mathbf{5 0 6}$ & $\mathbf{5 0 4}$ & $\mathbf{5 0 9}$ \\
\hline C38 & 498 & $\mathbf{5 0 5}$ & $\mathbf{5 0 9}$ & $\mathbf{5 0 2}$ & $\mathbf{5 0 4}$ & $\mathbf{5 0 6}$ & $\mathbf{5 0 4}$ & $\mathbf{5 1 0}$ \\
\hline
\end{tabular}

From table 5.5 and table 5.6 it can be observed that shear wall configuration system, the PSW system reduced the BM in the exterior column around $96 \%$ (C2 \& C4) \& about $99 \%$ in the interior column (C31 \& C38) compared with BF system. The remaining all other shear wall systems reduced the bending moments in both exterior and interior column about $93 \%$. the ISW system reduced the SF in the exterior column around $65 \%(\mathrm{C} 2 \& \mathrm{C} 4) \&$ about $76 \%$ in the interior column (C31 \& C38) compared with BF system.

\section{CONCLUSION}

1. All the shear wall configuration has given positive effect on the building in all the parameters.

2. In this study ESW, CSW and $2 \mathrm{CSW}$ lateral displacement has been reduced by around $81 \%, 80 \%$ and $82 \%$ respectively in comparison with Bare frame.
3. The displacement of all the Structural configurations are within the maximum limit prescribed by IS 1893-2002

4. The shear configuration gave a positive result in controlling the storey drifts effectively in the range of $50 \%$ to $89 \%$ except in the case of PSW where it reduces only $38 \%$ when compared to Bare frame.

5. The drift ratios of all the models are found to satisfy the limit prescribed by IS 1893-2002.

6. In this study ISW, ESW and PSW increased its base shear by $3.5 \%, 5 \%$ and $1.2 \%$ respectively. While other configurations are reduced in the range $0.5 \%$ to $1 \%$ when compared to bare frame

7. Provision of shear wall has improved in reducing the bending moment and shear force effect on the structure by an average of $98 \%$ and $86 \%$ respectively. 


\section{ACKNOWLEDGEMENT}

The authors sincerely thank former Professor and Head Prof. Prasad CSMV, Professor and Head Prof. Narendra Kumar $\mathrm{H}$, Department of Civil Engineering, and Dr. Puttaraju, Principal, SJB Institute of Technology, Bengaluru for their encouragement and for providing facilities to carry out this research work as a part of $\mathrm{M}$. Tech project.

\section{REFERENCES}

[1] Shahzad0Jamil Sardar, and Umesh0N. karadi,“"Effect of0Change in Shear Wall Location0on Storey Drift of Multistorey Building0Subjected to Lateral0Loads", International0Journal of Innovative0Research in Science, Engineering0and Technology, vol-2, issue-9, sep-2013.

[2] Karthick S, Uday Kumar S, Geetha G,"Study on lateral resistance behaviour of high rise building with shear wall and bracings", The international0journal of Science \&0technoledge, vol-4, issue-2, pp 65-70, feb2016.

[3] Shivanand C. Ghule, Sudeep H C, Rahul RavindraNaik et al, "Study of an irregular plan with different orientation of0shear wall in a high-rise structure The International0Journal Of Science \& Technoledge, ", vol-3, issue-5, pp 181-188, may2015.

[4] Priyanka0Soni, Purushottam lal Tamarakar, Vikky0Kumhar, "Structural analysis of multistory building of0different shear0walls location and heights", International Journal0of Engineering0Trends and Technology, vol-32, pp 5057, Feb-2016.

[5] Raghavendra, Sidarth Bejgum, Siddarth S Udgir, et al, "Seismic evaluation with shear walls and braces for buildings on sloping ground", International Journal of Innovative Research in Science, Engineering and Technology vol-5, issue-6, pp 10210-10219, June-2016.

[6] Samdani Azad, Syed Hazani Abd Gani, "Comparative study of seismic analysis of multistory buildings with shear walls and bracing systems", International Journal of Advanced Structures and Geotechnical Engineering, vol-5, pp 72-77, July2016.

[7] Shyam Bhat M, N A Permanand Shenoy, Asha U Rao, "Earthquake0behaviour of buildings with and without shear walls", International Conference on Innovations in Civil Engineering, pp 20-25, 2014.

[8] Ashish S .Agrawal, S D Charkha, "Effect of change in shear wall location on storey drift of multistory building subjected to lateral loads", International Journal of Engineering Research and Applications, vol-2, issue-3, pp 1786-1794, June-2012.

\section{BIOGRAPHIES}

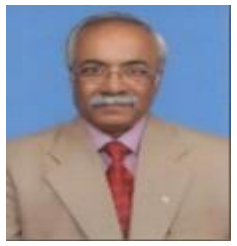

Dr. Rajeeva S V, presently working as an Engineering, SJBIT, Bengaluru. He has total teaching experience of 34 years. He obtained M. Tech from NITK, Surathkal and Ph.D. from IIT, Madras with a specialization in Structural Engineering. He has guided $48 \mathrm{M}$. Tech and $2 \mathrm{Ph} . \mathrm{D}$. thesis. He is a member of ACCE, IIBE, ICI, IE, ISET, ISTE.

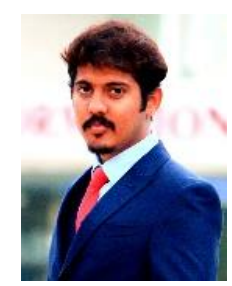

Mr. Abhishek K K, PG Student, M. Tech, Structural Engineering, at SJB Institute of Technology, Bengaluru. 